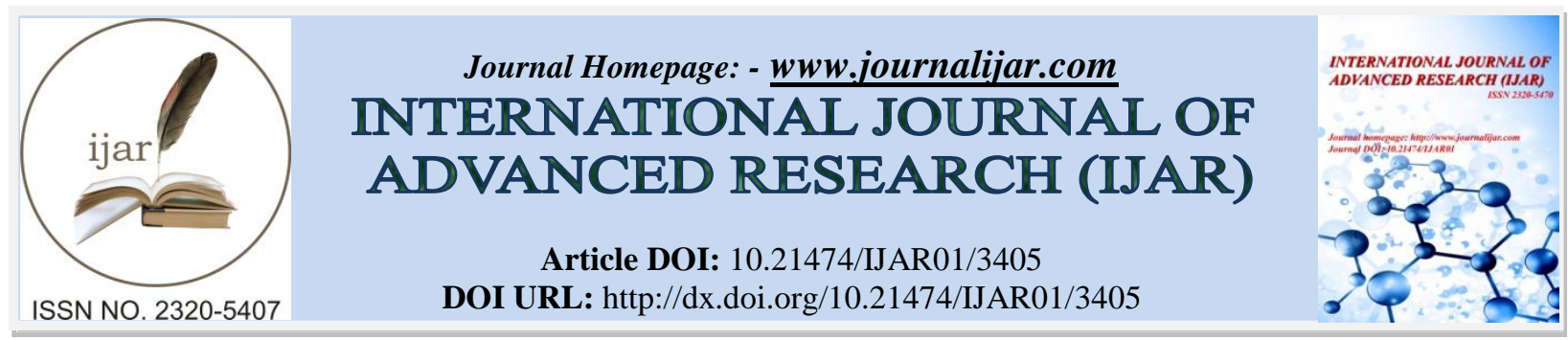

RESEARCH ARTICLE

\title{
EVALUATION OF IMMUNOGENICITY OF DNA VACCINE CODING OUTER MEMBRANE PROTEIN 31 (OMP31) OF BRUCELLA MELITENSIS IN MICE.
}

Yasser M. Kamel ${ }^{1}$, Noha A. Helmy ${ }^{2}$, Amani A. Hafez ${ }^{1}$ and Safaa M. Barghash ${ }^{3}$.

1. Infectious Diseases Unit, Animal Health Department, Desert Research Center, Cairo, Egypt.

2. Veterinary Serum and Vaccine Research Institute,Sera and Antigens Department, Abbasia, Cairo, Egypt.

3. Parasitology Unit, Animal Health Department, Desert Research Center, Cairo, Egypt.

\section{Manuscript Info}

\section{Manuscript History}

Received: 21 December 2016

Final Accepted: 23 January 2017

Published: February 2017

Key words:-

Subunit vaccine, B. melitensis, OMP31, Rev I vaccine, cytokines

\begin{abstract}
Brucellosis is causing serious medical and economic crisis, therefore there are many efforts to prevent infection through vaccination. Attenuated Br. Melitensis Rev 1 vaccine is considered the best vaccine available for now, but it has serious drawbacks. In the present work, Omp31 of B. melitensis vaccine (vectored vaccine) was evaluated in mice, in comparison with Br. Melitensis Rev 1 vaccine. The immune response showed similar and different trends. After vaccination, the vectored vaccine group showed nearly the similar trend in the TNF- $\alpha$, IL-1 $\alpha$ and IL-12 (p40) levels with lower levels of IL-10, an antiinflammatory cytokine, than B. Melitensis Rev 1 group. Moreover, vectored vaccine group showed lower weight, spleen and protective efficacy as those observed with B. Melitensis Rev 1vaccine. In addition, vectored vaccineism less biohazardous, well-defined and noninfectious. The obtained results document effectivity of the vectored vaccine and can be considered as a promising candidate and could be included in the development of a multi-subunit vaccine in controlling of brucellosis.
\end{abstract}

Copy Right, IJAR, 2017,. All rights reserved.

\section{Introduction:-}

Brucella belongs to $\alpha$-Proteobacteria causing many pathogenic problems in mammals including humans. Ruminant animals are susceptible to be infected by such bacterium all over the world. One of those affecting domestic livestock is B. melitensis that affect sheep and goats. Because domestic ruminants are a vital source for the economy income, especially in low income countries, brucellosis is considered as a main cause of direct economic losses. Therefore, its control and eradication is the most important goals of public health programs in endemic countries $(1,2)$.

Rev. 1 vaccine is formerly the only officially accepted vaccine for protection against B. melitensis infection, which induces significant protection in sheep and goats. On the other hand, the Rev1 vaccine can cause abortions, persisting agglutinins that can lead to mis diagnosis by using various serological tests in addition, it can infect humans through exposure to aerosols or accidental self-inoculation. $(3,4)$.

Subunit recombinant protein vaccines are considered promising vaccines because they are effective, less biohazardous, well-defined, non-infectious and persuade long-actingprotection [5, 6].Furthermore, it is essential to 
provoke an effective vaccine with adequate immunological response against intracellular microorganisms as Brucella species, particularly for T helper cell (Th1) where the production of certain cytokines as IFN $\gamma$, TNF $\alpha$, and IL-12 (p40) are necessary for control the infection as Th2 response has a marginal function in this respect. Antigen delivery systems become obligatory needed when antigens are not effectively transported to the suitable fitting sites or presented to the immune system [7]. Our work is aimed to evaluate vectored vaccine based on outer membrane protein 31 (OMP31) expressed by Escherichia coli (K12) as it is nonpathogenic strain and can deliver our protein to antigen presenting cells and hence, promoting cellular immune response to control the infection with $\mathrm{B}$. melitensisby using mice model [8].

\section{Materials and Methods:- Laboratory animals:-}

Forty-five female BALB/c mice with 4 to 6 week-old (obtained from a vet. Sera vacci Rec Institute-Cairo-Egypt) received one week previously, were distributed randomly into threegroups (fifteen for each). All mice were kept in cages and received water and food ad libitum.

\section{Strains of bacteria used:-}

For cloning and propagation of the concerned plasmid, Escherichia coli strain JM109 competent cells $>10^{8} \mathrm{cfu} / \mu \mathrm{g}$ (Promega, Madison, WI) were used while for recombinant protein expression, Escherichia coli strain K12 (Biolab, England) was applied.Bacteria strains were grown at $37^{\circ} \mathrm{C}$ in Luria-Bertoni (LB) brothor agar that supplemented with $100 \mu \mathrm{g} / \mathrm{ml}$ of ampicillin (9). For challenging purpose, B.melitensis $16 \mathrm{M}$ was used (obtained from vet. Sera vacci Rec Institute, Cairo, Egypt) and was cultured under optimal conditions in tryptose soya agar supplemented with yeast extract $10 \mathrm{~g} / \mathrm{lml}$ (Oxoid, England) incubated overnight at $37^{\circ} \mathrm{C}$ for $72 \mathrm{hrs}$ in $5 \% \mathrm{Co}_{2}$ to ensure sufficient cell density (10). The obtained bacteria were harvested and suspended in PBS and the abundance was adjusted to be $1 \times 10^{5} \mathrm{CFU} / 200 \mu \mathrm{l}$ for protection experiment.

\section{Amplification of Omp31 gene of $B$. melitensis 16M}

Extraction and measuring the DNA of B. melitensis 16M were performed by using the CTAB method as previously described (11). PCR amplification of Omp31 gene of B. melitensis 16M was done as described earlier (12) by using two primers, 31sd (5`-TGACAGACTTTTTCGCCGAA-3`) and 31ter (5`-CATTCAGGACAATTCCCGCC-3`). The primers were selected according to omp31 nucleotide sequence (13)

\section{Recombinant B. melitensis Omp31 protein:-}

DNA fragment (687-bp) of B. melitensis responsible for encoding Omp31was cloned in pCAGGS (Addgene, MA, USA), expressed in E. coli, and purified as designated before (14).Briefly, the obtained plasmid that contained Omp31 gene was amplified in transformed competent Escherichia coli (JM109) which were propagated in LB broth supplemented with $100 \mu \mathrm{g} / \mathrm{ml}$ of ampicillin (9) till reached $1 \mathrm{~nm}$ at OD600. Intact plasmid construction and function were confirmed via sequencing across the DNA inserted. The plasmid was isolated by using a Megaprep kit (Qiagen, Dorking, UK) and the DNA concentration was evaluated using spectrophotometry at 260/280 nm. COS-7 cells were transfected as stated by manufacture`s instructions with pCAGGS+Omp31 and Lipofectamine reagent to verify Omp31 expression which checked and confirmed by Western blotting with specific MAb A59/10F09/G010 as reported previously (15). The Limulus amebocyte lysate analysis kit [Sigma, St. Louis, Mo.] was used to corroborate the purity of rOmp31.

\section{Immunization of mice:-}

Mice were allocated randomly into three groups (fifteen mice in each group). The first group was vaccinated with the commonly used vaccination dose for commercial B. melitensis Rev 1 vaccine as positive control (16), the second group was immunized by I/P route with $0.2 \mathrm{ml}$ suspension of recombinant E.coli $\mathrm{K} 12\left(10^{7} \mathrm{CFU}\right)$ bearing pCAGGS plasmid containing omp31 gene (vectored vaccine)in phosphate buffer saline (PBS, pH 7.2). The colony forming units per ml was adjusted at OD $600 \mathrm{~nm}\left(\mathrm{OD}_{600}\right)$ and the injected dose was determined retrospectively by triple plating onto tryptic soya agar supplemented with yeast extract. Finally, the third group was received PBS as negative control. 


\section{Protection Experiments and evaluation of Brucella strain persistence:-}

To evaluate the efficacy of vectored vaccine for protection against B.melitensis infection, five mice from each group was challenged by intra peritoneal route (I.P) with approximately $1 \times 10^{5} \mathrm{CFU} /$ mouse of B.meletensis $16 \mathrm{M}$. On the $30^{\text {st }}$ day after vaccination, the mice were euthanized by cervical dislocation; their spleens were removed aseptically and weighed.The persistence of challenging strain of B.meletensisM16in mice was determined as described previously $(9,17)$, by determination of B.meletensis CFU in the spleen. The obtained spleens from five mice in each group were macerated individually and homogenized, Ten-fold serial dilution in PBS were plated onto tryptic soy agar supplemented with yeast extract and incubated to determine the bacterial count.The experiment was conducted twice, and the results were represented as means \pm SD $(n=5)$ of the log CFU/spleen. Log units of protection were calculated via subtracting the mean $\log \mathrm{CFU}$ of the vaccinated group from the mean $\log \mathrm{CFU}$ of the control immunized group.

\section{Measurement of immune response against Omp31:-}

Indirect enzyme-linked immunosorbent assay (ELISA) was subjected to determine the antibody response against Omp31 in collecting sera (17).Serum titers of Antibody evaluated as the highest serum dilution inverse yielding value at $\mathrm{OD}_{405}$ two times higher that of the dilution buffer (blank). The titer of IgG was recorded as means $\pm \mathrm{SD}$ of the $\log$ of the titers taken from five mice analyzed individually. Regarding the evaluation of Cytokine levels in the spleens of immunized mice in response to the injected vaccines (vectored vaccine and B.melitensis Rev1), five mice from each group were vaccinated as described above and their spleens were collected at 0, 7, 14, 21 and 28 dpi (prechallenge period in protection experiments). CHAPS detergent (Thermo Fisher scientific, USA) was added (1\% final concentration) to the homogenated mouse spleens in PBS to maintain protein activity and lysis the splenocytes $[18,19]$. cell debris was separated and removed by centrifugation afterone hour incubation at $4{ }^{\circ} \mathrm{C}$, and the supernatants were kept at $-80{ }^{\circ} \mathrm{C}$ till use for cytokine quantification. The collected supernatants were subjected to sandwich ELISA to quantify the levels of interferon- $\gamma$ (IFN- $\gamma$ ), tumornecrosis factor- $\alpha$ (TNF- $\alpha$ ), interleukin- $1 \alpha$ (IL-

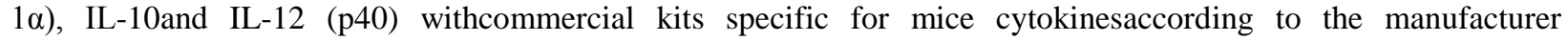
instructions (BD Biosciences, SanDiego, USA) asillustrated before [20]. The results were recorded for each immunized group as means \pm SD of the detected cytokine quantity (ng) in the spleens of five individual mice at each point of time.

\section{Statistical Analysis:-}

Data obtained were expressed as mean \pm standard error of the mean. It was analyzed using SPSS version 18.0 (IBM SPSS Statics 18, USA). Data were subjected to one-way analysis of variance (ANOVA) and the post-hoc test was applied for multiple comparisons. Values of $\mathrm{P}<0.05$ and $\mathrm{P}<0.001$ were regarded as statistically significant and highly significant, respectively.

\section{Results:-}

Inflammatory response of used vaccines:-

Spleen weight was taken as an indicator to compare the degree of inflammatory response in vaccinated groups. The vectored vaccine did not induce significant inflammatory response on the assay span while Rev1 group showed a strong response that reached its maximum level at $14^{\text {th }}$ day post inoculation at which the spleen weight reached 4 times higher than that of vectored vaccine group, as illustrated in Figure 1. 


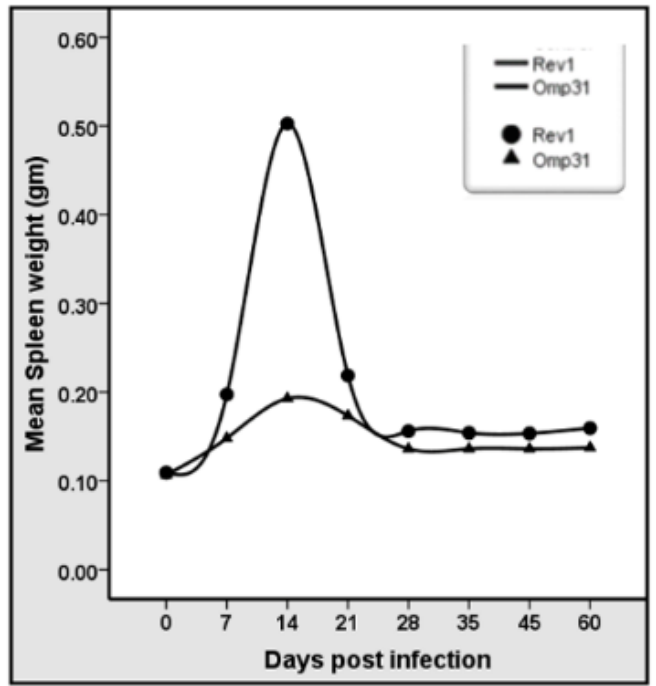

Figure 1:- Estimation of spleen weight in vaccinated mice

Results are expressed as means $\pm \mathrm{SD}(\mathrm{n}=5)$ of the spleen weight at each point of time.

\section{Humeral immunity response against B. melitensis:-}

The serum immunoglobulin $\mathrm{G}$ (IgG) level was estimated in the mice of protection experiment up to day 28 post inoculation (before challenge) with either PBS (control negative), Rev1 attenuated vaccine or vectored vaccine. In mice vaccinated with Rev1vaccine, the titer of $\operatorname{IgG}$ was detected in the $7^{\text {th }}$ day after inoculation and increased progressively up to the end of the experiment while the $\mathrm{IgG}$ level was higher in mice vaccinated with vectored vaccine along the experiment. In comparison, the antibody response in the Rev 1 vaccinated group was delayed and first detection was on $14^{\text {th }}$ day post inoculation and was lower than that noticed with vector vaccinated mice at all time-points checked, as shown in Figure 2.

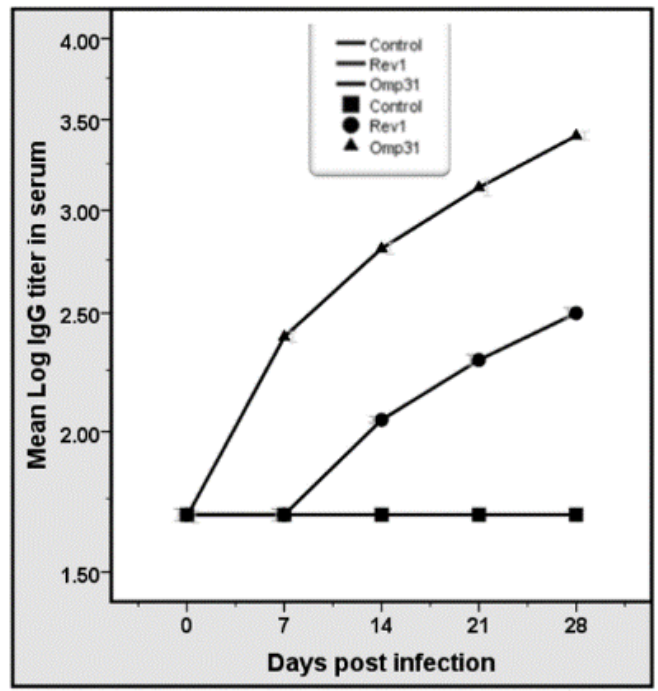

Figure 2:-The antibody responses in mice sera

Results are expressed as means $\pm \mathrm{SD}(\mathrm{n}=5)$ of the $\log$ of $\operatorname{IgG}$ titers by ELISA at each point of time.

\section{Detection of spleen cytokines in mice:-}

The cytokine level in spleen of inoculated mice was estimated until the day 28 post infection. Spleen of vaccinated mice with Rev1 vaccine showed the highest level of TNF- $\alpha$, INF- $\gamma$, IL-1a, IL-10 and IL-12 (p40). Except IL-10, all cytokines in Rev 1 vaccinated group showed high levels and reached the peak at day 14 post inoculation then, begin to decrease until the day 28 at which all cytokines of the other group had profile too large extent like those evaluated in control negative group (PBS inoculated). Regarding IL-10, it has the similar trend, but its highest level was 
detected on day 21 post inoculation. The strongest response was detected with both IL-1a and IL-12 (p40) in the maximum concentrations around 11ng per spleen followed by the level of INF- $\gamma$ that record about 6 ng per spleen whereas the level of TNF- $\alpha$ and IL-10 showed the lowest recorded levels about $1.6 \mathrm{ng}$ and $2 \mathrm{ng}$ per spleen, respectively. Mice of vaccinated group with opm31also induced cytokine production like, but to a lesser extent those of the Rev1 vaccinated group, except for IL-10 level that scored concentrations did not show statistically significant differences with those of control group (Figure 3, A-E).
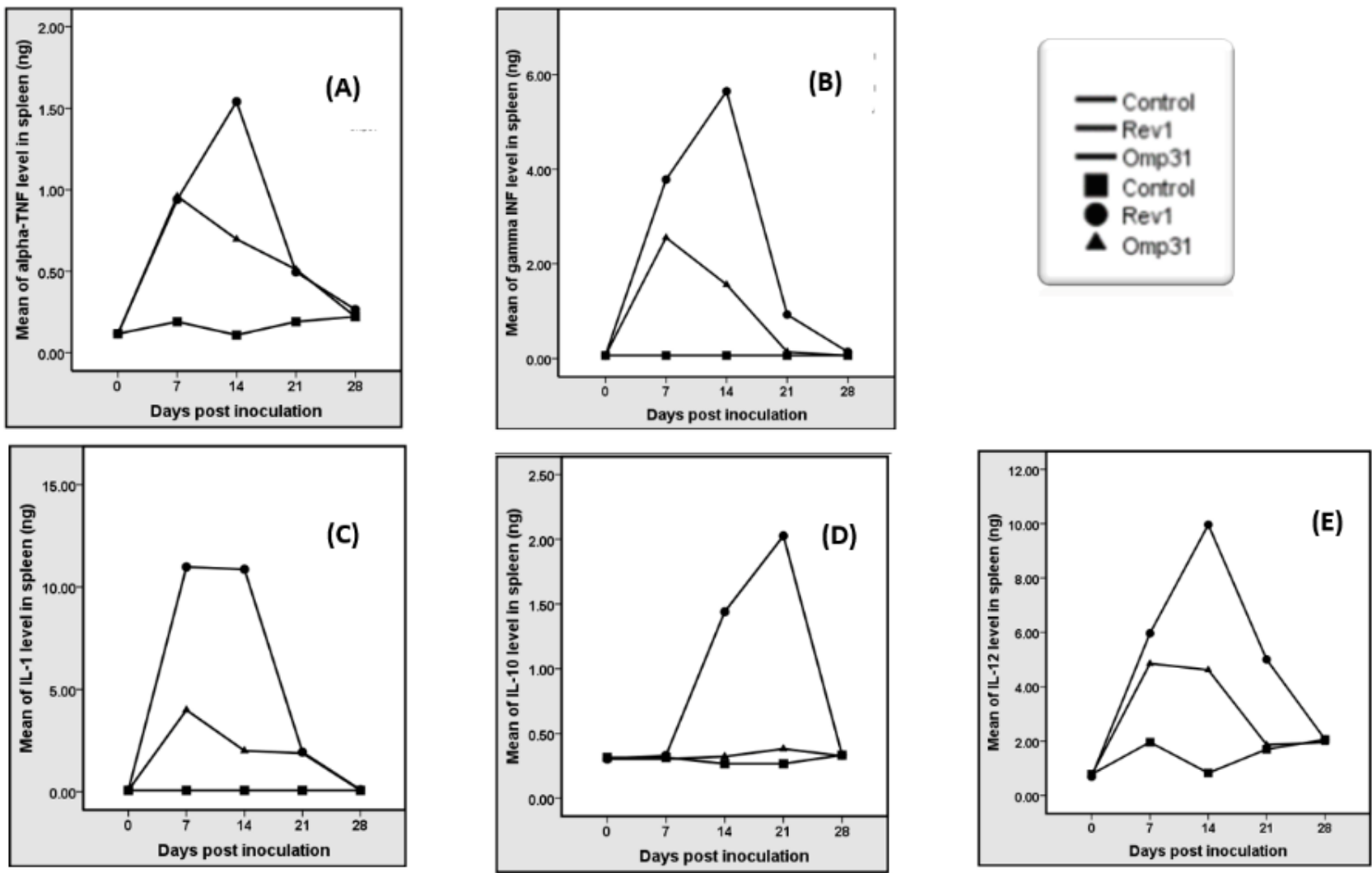

Figure 3:- evaluation of the levels of cytokines in spleen of mice

TNF- $\alpha$ (A), INF- $\gamma(B)$, IL-1 $\alpha$ (C), IL-10 (D), and IL-12(p40)(E). Results are expressed as means \pm SD (n=5) of each amount of cytokine in spleen at each point of time.

The challenge Experiment:-

All groups were inoculated with a virulent strain of Brucella melitensis M16 in a dose of $0.9 \times 10^{5}$ at the day 28 after vaccination. After three weeks of infection, the bacteria in spleen were counted. The challenge result revealed that the rev 1 and vectored vaccines conferred nearly the same protection (P.0.05). In comparison with the control group, the two used vaccines induced reduction in the bacterial load in the mice spleen about three log units (Figure 4). 


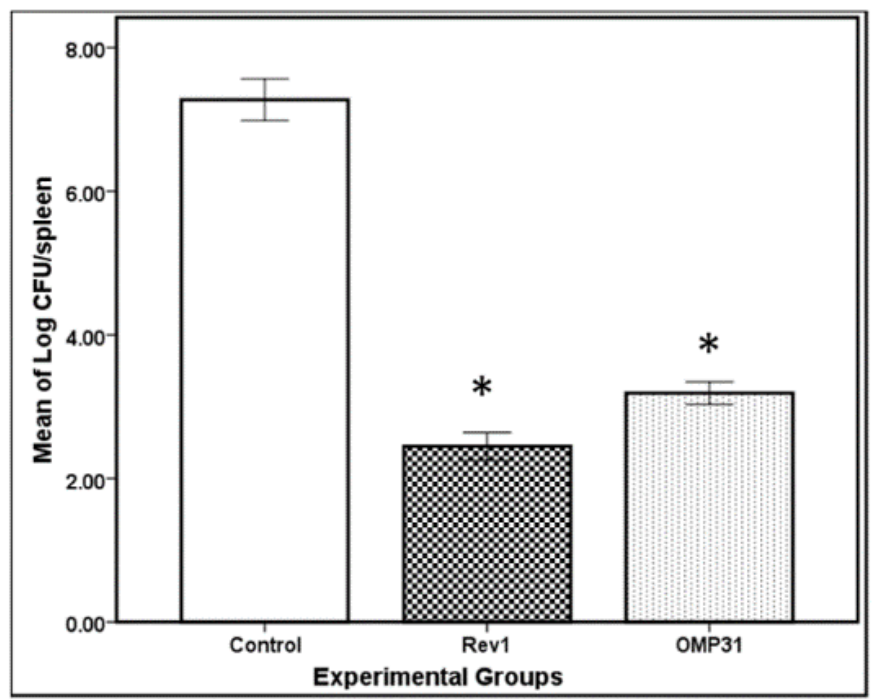

Figure 4:- Protection against virulent Brucella melitensis M16 strain by the Brucella vaccines in mice.

Results are expressed as means \pm SD $(n=5)$ of the log of the CFU/spleen. Significant differences between mice immunized with each vaccine and control mice inoculated with PBS are marked with (*) that means high significant $(\mathrm{P} \leq 0.001)$.

\section{Discussion:-}

Researchers and scientists working in the field of the disease control are always do their best to discover and synthesis alternative vaccines to live attenuated strains to be able to fend off infections especially those burden the human being health. Currently, the best choice available vaccine against Brucella spp. is B. melitensis Rev1 vaccine $(21,22)$. So, it was used to be the reference in our study to compare the efficacy of our recombinant vaccine. Nevertheless, it has significant disadvantages that may constrict its usage. As it is live attenuated vaccine, not completely safe, there is high probability to be a potential bioterrorism agent (23), cause severe complications in immunocomprimised animals (24), cause abortion, difficult to transport and delivery where it needs special requirement to maintain condition and creates serological immune responses against $\mathrm{O}$ that causes interference in interpretation of many serological tests especially in the discrimination between natural infected and vaccinated animals (25). In contrast, recombinant proteins based vaccines, are less biohazardous, well defined composition, avirulent and non-infectious (6).

Subunit vaccines have been studied for years and have not given sufficient protection against Brucella spp. (26). Many approaches had been taken for development of vaccines based on bacterial recombinants (27). One of these approaches consists of expressing the foreign antigen on the surface of transfected bacteria. Subcellular vaccines could shun the drawbacks of live attenuated vaccines where is being safer in manipulation, not causing abortion and not interfering with immunodiagnostic tests as it has different antigen (28) and having the capacity to trigger the both arms on the immune system (29).

The better protective activity for the Rev1 vaccine was forecasted and detected by the evidences of the strong inflammatory response, as increasing the immunized mice spleen weight and cytokine profiles than those provoked by vectored vaccine( Figure 1 and 2). On the other hand, the protection granted by vectored vaccine vaccine against the experimental B. Melitensis infection was closely equipollent to that offered by B. melitensis Rev1 vaccine (Figure 5). The obtained result may be attributed to many factors and reasons. The first is the greater antibodies production able them to bind the virulent inoculated B. melitensis strain that detected in vaccinated mice with vectored vaccine(Figure 3) and opsonized them to facilitate their phagocytosis (29). This give an advantage to our recombinant vaccine and proves the fact that the antibodies have a greater impact in the protective immunity against B. melitensis than that for lymphocytes (30). The second reason, it is well known that INF- $\gamma$ is playing the essential and vital role in controlling the Brucella infections whereas it stimulates the bactericidal function in macrophages $(31,32)$, INF- $\gamma$ recorded notable high level in both vaccinated groups (Figure 3-B). Third, the stoner response of splenocytes from B. melitensis Rev1 mice vaccinated group in production of more IL-1 $\alpha$, which has potent stimulation of T-helper (CD4) and T-cytotoxic (CD8) lymphocytes against the inoculated antigen (33) than 
splenocytes gained from mice either vaccinated with vectored vaccineor non-vaccinated group (Figure 3-C). Finally, splenocytes of B. melitensis Rev1 mice vaccinated group induced powerful IL-10 response. It was established that IL-10 has anti-inflammatory effect $(34,35)$, this fact gives an advantage to our tested vaccine over the commercial used one.

Another positive aspect of vectored vaccineis the protective function that comes with slight degree of inflammatory response $(36,37)$. On the other hand,the smooth lipopolysaccharide (S-LPS) represents the main component in B. melitensis Rev1 vaccine $(38,39)$ therefore, severe inflammatory response would be occurred leading to shock or even death $(40,41)$ when the body exposed to LPS in an excessive or systemic manner via blood. According to our results, vectored vaccine stimulate and enhance solid immune response with triggering both Th1 and Th2 lymphocytes cytokines in a form making it capable to control B. melitensis infection as professionally as vaccination with B. melitensis Rev 1. In taking into account the disadvantages of vaccination with B. melitensis Rev $1(42,43)$, the Omp31 depending vaccine constitutes a promising candidate and could be included in the development of a multi-subunit vaccine in controlling of brucellosis.

\section{Acknowledgement:-}

The present study was achieved in the frame of PROCAMED project, supported by the European Union (Trans frontier cooperation in the frame of European Neighborhood and Partnership Instrument-Joint Operational Programme of the Mediterranean Basin (IEVP-CT), managed by the Joint Managing Authority- Autonomous Region of Sardinia( Italy) and coordinated by CIRAD-France. Many thanks for the help of Prof. Dr. Mohamed khodeir and Prof. Dr Saleh ElAyoubi.

\section{References:-}

1. Jinkyung K., and A. S. Gary. 2003. Molecular Host-Pathogen Interaction in Brucellosis: Current Understanding and Future Approaches to Vaccine Development for Mice and Humans. Clin. Microbe. Rev. 65-78.

2. Moriyon I, M.J. Grillo, D. Monreal,D. Gonzalez, C. Marin,I. Lopez-Gonii, . R.C. Mainar-Jaime, E. Moreno, and J.M. Blasco. 2004. Rough vaccines in animal brucellosis : Structural and genetic basis and present status. Vet. Res. $35: 138$.

3. Fernandez-Prada, C. M., M. Nikolich, R. Vemulapalli, N. Sriranganathan, S. M. Boyle, G. G. Schurig, T. L. Hadfield, and D. L. Hoover. 2001. Deletion of wboA enhances activation of the lectin pathway of complement in Brucella abortus and Brucella melitensis. Infect. Immun. 69:4407 4416.

4. Schurig G.G., N. Sriranganathan and M.J Corbel. Brucellosis vaccines: past, present and future. Vet Microbiol 2002;90:479-96.

5. S.D. Perkins, S. J. Smither, and H. S. Atkins, "Towards a Brucella vaccine for humans," FEMSMicrobiology Reviews, vol. 34, no. 3, pp. 379-394, 2010.

6. K. A. Pasquevich, A. E. Ibãnez, L. M. Coria et al., "An oral vaccine based on U-Omp19 induces protection against B. abortus mucosal challenge by inducing an adaptive IL-17 immune response in mice," PLoS ONE, vol. 6, no. 1, article e16203, 2011.

7. C. Ruecker and C. A.Guzm'an, "Vaccines: from empirical development to rational desing," PLOS Pathogens, vol. 8, no. 11, Article ID e1003001, 2012.

8. V. K. Gupta, G. Radhakrishnan, J.Harms, and G. Splitter, "Invasive Escherichia coli vaccines expressing Brucella melitensis outer membrane proteins 31 or 16 or periplasmic protein BP26 confer protection in mice challenged with B. melitensis," Vaccine, vol. 30, no. 27, pp. 4017-4022, 2012.

9. Estein, S. M., J. Cassataro, N. Vizcaino, M. S. Zygmunt, A. Cloeckaert, and R. A. Bowden. 2003. The recombinant Omp31 from Brucella melitensis alone or associated with rough lipopolysaccharide induces protection against Brucella Ovis infection in BALB/c mice. Microbes Infect. 5:85-93.

10. Al-Mariri, A., A. Tibor, P. Mertens, X. De Bolle, P. Michel, J. Godefroid, K. Walravens, and J. J. Letesson. 2001. Protection of BALB/c mice against Brucella abortus 544 challenge by vaccination with bacterioferritin or P39 recombinant proteins with $\mathrm{CpG}$ oligodeoxynucleotides as adjuvant. Infect. Immun. 69:4816-4822.

11. Kamel, M. Y, Noha A. H and Amani A. H. 2014. Different Dna Extraction Techniques from Brucella melitensis 16M. Int J Microbiol Res 5 (1): 69-75.

12. Vizcaõ̂Âno N, Verger J-M, Grayon M, Zygmunt MS, Cloeckaert A. 1997. DNA polymorphism at the omp-31 locus of Brucella spp; evidence for a large deletion in Brucella abortus and other species-speci@c markers. Microbiology; 143:2913 \pm 21 . 
13. VizcaõÂno N, Cloeckaert A, Zygmunt MS, Dubray G. 1996. Cloning, nucleotide sequence, and expression of the Brucella melitensis omp31 gene coding for an immunogenic major outer membrane protein. Infect Immun;64:3744 \pm 51

14. Cassataro, J., K. Pasquevich, L. Bruno, J. C. Wallach, C. A. Fossati, and P. C. Baldi. 2004. Antibody reactivity to Omp31 from Brucella melitensis in human and animal infections by smooth and rough brucellae. Clin. Diagn.Lab Immunol. 11:111-114.

15. Cloeckaert, A., M. S. Zygmunt, P. de Wergifosse, G. Dubray, and J. N. Limet.1992. Demonstration of peptidoglycan-associated Brucella outer-membrane proteins by use of monoclonal antibodies. J. Gen. Microbiol. 138:1543-1550.

16. Grilló MJ, Blasco JM, Gorvel JP, Moriyón I, Moreno E: (2012): What have we learned from brucellosis in the mouse model? Vet Res, 43:29.

17. Guilloteau, L. A., K. Laroucau, N. Vizcaino, I. Jacques, and G. Dubray. 1999. Immunogenicity of recombinant Escherichia coli expressing the omp31 gene of Brucella melitensis in BALB/c mice. Vaccine17:353-361.

18. Fernández-Lago L, Monte M, Chordi A: Endogenous gamma interferon and interleukin-10 in Brucella abortus 2308 infection in mice. FEMS Immunol Med Microbiol 1996, 15:109-114.

19. Fernández-Lago L, Rodríguez-Tarazona E, Vizcaíno N: Differential secretion of interleukin-12 (IL-12) subunits and heterodimeric IL-12p70 protein by CD-1 mice and murine macrophages in response to intracellular infection by Brucella abortus. J MED Microbiol 1999, 48:1065-1073.

20. Fernández-Lago L, Orduña A, Vizcaíno N: Reduced interleukin-18 secretion in Brucella abortus 2308-infected murine peritoneal macrophages and in spleen cells obtained from B. abortus 2308-infected mice. J MED Microbiol 2005, 54:527-531.

21. Blasco JM, 1997. A review of the use of B. melitensis Rev 1 vaccine in adult sheep and goats. Prev Vet MED 31:275-283.

22. Godfroid J, Scholz HC, Barbier T, Nicolas C, Wattiau P, Fretin D, Whatmore AM, Cloeckaert A, Blasco JM, Moriyón I, Saegerman C, Muma JB, Al Dahouk S, Neubauer H, Letesson JJ, 2011: Brucellosis at the animal/ecosystem/human interface at the beginning of the 21st century. Prev Vet MED, 102:118-131

23. Kaufmann, A. F., M. I. Meltzer, and G. P. Schmid. 1997. The economic impact of a bioterrorist attack: are prevention and postattack intervention programs justifiable? Emerg. Infect. Dis. 3:83-94.

24. Kroger, Andrew T.; Ciro V. Sumaya; Larry K. Pickering; William L. Atkinson (2011). "General Recommendations on Immunization: Recommendations of the Advisory Committee on Immunization Practices (ACIP)". Morbidity and Mortality Weekly Report (MMWR). Centers for Disease Control and Prevention. Retrieved 2011-03-11.

25. Hasanjani-Roushan MR, Kazemi S, Fallah-Rostami F, Ebrahimpour S. 2014. Brucellosis vaccines: an overview. Crescent J MED Biol Sci;1(4):118-124.

26. TabatabaõE LB, Pugh GW, Jr. 1994. Modulation of immune responses in BALB/c mice vaccinated with Brucella abortus $\mathrm{Cu}-\mathrm{Zn}$ superoxide dismutase synthetic peptide vaccine. Vaccine,12:919-24.

27. Ertl HCJ, Xiang Z. 1996. Novel vaccine approaches. J Immunol; 156:3579-82.

28. Cassataro J, Velikovsky CA, de la Barrera S, Estein SM, Bruno L, Bowden R, Pasquevich KA, Fossati CA, Giambartolomei GH, 2005: A DNA vaccine coding for the Brucella outer membrane protein 31 confers protection against B. melitensis and B. ovis infection by eliciting a specific cytotoxic response. Infect Immun, 73:6537-6546.

29. Leclercq S, Harms JS, Olivereia SC. 2003. Enhanced capacity of DNA vaccines against an intracellular bacterial pathogen by genetic adjuvants. Curr Pharm Biotechnol, 4: 99-107.

30. Ko, J., and G. A. Splitter. 2003. Molecular host-pathogen interaction in brucellosis: current understanding and future approaches to vaccine development for mice and humans. Clin. Microbiol. Rev. 16:65-78.

31. Jiménez de Bagüés MP, Elzer PH, Blasco JM, Marín CM, Gamazo C, Winter

32. AJ. 1994. Protective immunity to Brucella Ovis in BALB/c mice following recovery from primary infection or immunization with subcellular vaccines. Infect Immun, 62:632-638.

33. Murphy EA, Sathiyaseelan J, Parent MA, Zou B, Baldwin CL. 2001. Interferon-gamma is crucial for surviving a Brucella abortus infection in both resistant C57BL/6 and susceptible BALB/c mice. Immunology, 103:511518.

34. Ben-Sasson SZ, Caucheteux S, Crank M, Hu-Li J, Paul WE. 2011. IL-1 acts on T cells to enhance the magnitude of in vivo immune responses. Cytokine, 56:122-125.

35. Rutz S, Ouyang W. 2011. Regulation of interleukin-10 and interleukin-22 expression in T helper cells. Curr Opin Immunol, 23:605-612. 
36. Corsetti PP, de Almeida LA, Carvalho NB, Azevedo V, Silva TM, Teixeira HC, Faria AC, Oliveira SC. 2013. Lack of endogenous IL-10 enhances production of proinflammatory cytokines and leads to Brucella abortus clearance in mice. PLoS One, 8:e74729.

37. Arenas-Gamboa AM, Ficht TA, Kahl-McDonagh MM, Gomez G, Rice-Ficht AC. 2009. The Brucella abortus S19 $\Delta$ vjbR live vaccine candidate is safer than S19 and confers protection against wild-type challenge in $\mathrm{BALB} / \mathrm{c}$ mice when delivered in a sustained-release vehicle. Infect Immun, 77:877-884.

38. Arenas-Gamboa AM, Ficht TA, Kahl-McDonagh MM, Rice-Ficht AC. 2008. Immunization with a single dose of a microencapsulated Brucella melitensis mutant enhances protection against wild-type challenge. Infect Immun, 76:2448-2455.

39. Wright PF, Nielsen KH. 1990. Current and future serological methods. In Advances in brucellosis research. Edited by Adams LG. College Station. USA:Texas A\&M University Press, 1990.

40. Zygmunt MS, Debbarh HS, Cloeckaert A, Dubray G. 1994. Antibody response to Brucella melitensis outer membrane antigens in naturally infected and Rev1 vaccinated sheep. Vet Microbiol, 39:33-46.

41. Erridge C, Bennett-Guerrero E, Poxton IR. 2002. Structure and function of lipopolysaccharides. Microbes and Infection. 4:837-851. doi: 10.1016/S1286-4579(02)01604-0.

42. Bowden RA, Cloeckaert A, Zygmunt MS, Bernard S, Dubray G. 1995. Surface exposure of outer membrane protein and lipopolysaccharide epitopes in Brucella species studied by enzyme-linked immunosorbent assay and flow cytometry. Infect Immun. 63:3945-52.

43. Blasco JM. 1997. A review of the use of B. melitensis Rev 1 vaccine in adult sheep and goats. Prev Vet MED 31:275-283.

44. Grilló MJ, Bosseray N, Blasco JM. 2000. In vitro markers and biological activity in mice of seed lot, strains and commercial Brucella melitensis Rev 1 and Brucella abortus B19 vaccines. Biologicals, 28:119-127. 